\section{Transmission of Xylella fastidiosa through Pecan Rootstock}

\author{
R. S. Sanderlin ${ }^{1}$ and R. A. Melanson \\ Louisiana State University Agricultural Center, Pecan Research-Extension \\ Station, PO Box 5519, Shreveport, LA 71135
}

Additional index words. Carya illinoinensis, graft transmission, pecan bacterial leaf scorch

Abstract. Xylella fastidiosa Wells et al., the pathogen that causes pecan [Carya illinoinensis (Wangenh.) C. Koch] bacterial leaf scorch disease, was demonstrated to be highly transmissible through graft unions from infected rootstock into new growth developing from scions. Infected rootstocks were obtained by inoculation of pecan seedlings in pots with in vitro cultures of the pathogen. If rootstock infection occurs in nature, transmission of the pathogen into tissue growing from scions could serve as a significant source of introduction of the disease into pecan orchards. Because symptom development in infected trees typically begins in midsummer and grafting takes place in the early spring, it would be difficult to identify infected rootstock before grafting. Commercial pecan growers sometimes attempt to eliminate bacterial leaf scorch from trees by regrafting to other cultivars. The high rate of transmission from infected rootstocks observed in this test and the lack of knowledge of cultivars with resistance to the disease makes this practice ineffective.

Pecan [Carya illinoinensis (Wangenh.) C. Koch] is one of the few economically important crops native to North America. It is grown commercially in its native range of the United States, and production has expanded into nonnative areas of the southeastern United States and into some of the western states including Arizona, New Mexico, and California. Pecan cultivars are clonally propagated with scion wood or buds grafted onto rootstocks that are grown from seed.

Pecan bacterial leaf scorch (PBLS) disease, incited by Xylella fastidiosa Wells et al., has a chronic course and is able to cause defoliation and economically significant crop loss in severely infected trees (Sanderlin and Heyderich-Alger, 2000, 2003). The modes of introduction of the pathogen into pecan orchards has not been completely established; however, the pathogen can be transmitted into new growth from infected scions (Sanderlin, 2005). Thus, use of scion wood from infected trees could be a significant source of pathogen introduction into orchards. If pecan propagators try to avoid collecting scions from infected sources, it becomes equally important to know whether the pathogen can be transmitted from infected rootstock into trees developing from uninfected scions. In addition, pecan growers sometimes try to eliminate trees with PBLS in their orchards by regrafting diseased trees to other cultivars. The purpose of this study was to verify that the pathogen can be passed from infected seedling rootstock into newly developing grafts.

Received for publication 17 Mar. 2006. Accepted for publication 21 Apr. 2006.

${ }^{1}$ To whom reprint requests should be addressed; e-mail rsanderlin@agcenter.lsu.edu.

\section{Materials and Methods}

To test for rootstock transmission of the pathogen, infected and uninfected trees in pots were grafted to healthy scions. Infected rootstocks were obtained from a group of pecan seedlings that had been inoculated with in vitro isolates of $X$. fastidiosa in 2001 (Sanderlin, 2005). Uninfected seedlings inoculated with distilled water in 2001 served as uninfected rootstocks. The seedlings had been grown from seed of several cultivars (Table 1 ). The potted seedlings were maintained in a greenhouse. Prior assays using an enzymelinked immunosorbent assay (ELISA) kit (Agdia, Inc., Elkhart, Ind.) were used to estimate the presence or absence of $X$. fastidiosa. Uninfected scions were collected in Feb. 2004 from a 'Cape Fear' tree and an ungrafted tree grown from a 'Riverside' nut, and were stored wrapped in moist paper towels near $4{ }^{\circ} \mathrm{C}$ until used for grafting in May. The scion sticks were 0.5 to $1.0 \mathrm{~cm}$ in diameter and about $15 \mathrm{~cm}$ long. Grafting was carried out using the four-flap technique (Vanerwegen, 1975). In 2004, 25 infected rootstocks and 12 uninfected rootstocks were used. The growth that developed from the scions was visually evaluated for PBLS symptoms through the summer and assayed by ELISA for the bacterium two or three times during Sept. and Oct. 2004 and again in Sept. 2005.

The test was repeated in 2005 using the same procedures with other seedlings that had been inoculated with either $X$. fastidiosa or distilled water in 2001. Scions used in 2005 were collected in February. and came from either an uninfected 'Pawnee' tree or an uninfected, ungrafted tree grown from a 'Riverside' nut. Twenty-five infected rootstocks and 10 uninfected rootstocks were grafted in 2005. Developing growth from the scions was monitored for symptoms and assayed for infection by ELISA in September and Oct. 2005. The data from each year were combined, and statistical significance evaluated by the chi-square test.

\section{Results and Discussion}

The overall graft success rates were low $(54.5 \%$ for grafts on uninfected rootstocks and $40 \%$ on infected rootstocks), probably because the trees had been confined to small pots for several years and were in poor nutritional condition.

In 2004, infected rootstocks came from six seed sources and uninfected rootstocks came from five of the same six seed sources (Table 1). Eleven of the 12 successful grafts on infected rootstocks developed PBLS symptoms in either 2004 or 2005, and 10 of these tested positive for $X$. fastidiosa infection in at least one of the serological assays during 2004 and 2005 (Table 1). Six of the seven trees developing from the healthy rootstock grafts did not exhibit scorch symptoms and all seven tested negative for infection.

Scorchlike symptoms were recorded on one of the trees developing from a graft on an uninfected rootstock and one from a graft on an infected rootstock that tested negative for $X$. fastidiosa in several serological assays. It is probable that these two developing trees were not infected because there are other problems that can mimic the symptoms of bacterial leaf scorch, including drought and nutritional imbalances.

Eight infected rootstocks from four seed sources were grafted in 2005; seven of these tested positive for infection before the end of the year (Table 2). The five grafts onto uninfected rootstocks all tested negative for infection. Scions from all sources used ('Cape Fear', 'Pawnee', and ungrafted 'Riverside' seedling) became infected when grafted onto diseased rootstocks.

During the 2 -year period, $85 \%$ of the trees that developed after grafting onto infected rootstock became infected with the bacterium. None of the trees grafted onto uninfected rootstock were infected. The chi-square test was highly significant $(P<0.0001)$ for $X$. fastidiosa transmission from infected rootstock after grafting. This clearly demonstrates the ability of the pathogen to pass into newly developing grafts at a high rate through the rootstock-scion union. Because of the high rate of pathogen transmission through infected rootstock, regrafting pecan trees as a means of reducing the incidence of the disease is not an effective control measure, particularly because cultivars resistant to PBLS have not been identified.

The ability of the pathogen to pass easily through pecan graft unions from infected rootstocks and from infected scions into newly developing growth may represent one of the primary ways that the pathogen is introduced into new orchard plantings. The rootstocks used in this test were infected through artificial inoculation using in vitro isolates of the pathogen. Pecan nurseries will 


\begin{tabular}{|c|c|c|c|c|c|c|c|c|c|c|}
\hline \multirow{2}{*}{$\begin{array}{l}\text { Rootstock seed source and } \\
\text { test tree number }\end{array}$} & \multicolumn{10}{|c|}{ Symptoms and serology ${ }^{y}$} \\
\hline & \multicolumn{2}{|c|}{8 Sept. 2004} & \multicolumn{2}{|c|}{14 Sept. 2004} & \multicolumn{2}{|c|}{24 Sept. 2004} & \multicolumn{2}{|c|}{22 Oct. 2004} & \multicolumn{2}{|c|}{6 Sept. 2005} \\
\hline \multicolumn{11}{|l|}{ Infected } \\
\hline Barton II & & & - & - & & & + & + & + & + \\
\hline Cape Fear I & & & + & + & + & - & & & + & + \\
\hline Cheyenne I & - & - & + & + & & & + & + & - & - \\
\hline Cheyenne II & & & + & + & & & - & + & + & + \\
\hline Kiowa I & - & + & + & + & & & & & + & + \\
\hline Kiowa II & - & - & - & - & & & & & + & + \\
\hline Kiowa III & - & + & + & + & & & & & + & + \\
\hline Kiowa IV & + & + & + & + & & & & & + & + \\
\hline Schley I & & & - & - & & & - & - & - & - \\
\hline \multicolumn{11}{|l|}{ Uninfected } \\
\hline Barton I & & & - & - & - & - & & & - & - \\
\hline Schley I & & & - & - & & & - & - & - & - \\
\hline Schley II $^{\mathrm{x}}$ & & & - & - & - & - & & & & \\
\hline
\end{tabular}

${ }^{2}$ Rootstocks were grown from seed of listed cultivars, inoculated with Xylella fastidiosa or distilled water in 2001, and grafted to uninfected scions of 'Cape Fear' or a 'Riverside' seedling tree in 2004.

'Presence $(+)$ or absence $(-)$ of symptoms of pecan bacterial leaf scorch were recorded at the time tissue was taken for serological assay, date shown. Ser (+) or $(-)$ indicates a positive or negative enzyme-linked immunosorbent assay for $X$. fastidiosa.

${ }^{x}$ This tree died during 2005 .

Table 2. Results of 2005 rootstock transmission of Xylella fastidiosa test.

\begin{tabular}{|c|c|c|c|c|}
\hline \multirow{3}{*}{$\begin{array}{l}\text { Rootstock seed } \\
\text { source and test } \\
\text { tree number }\end{array}$} & \multicolumn{4}{|c|}{ Symptoms and serology } \\
\hline & \multicolumn{2}{|c|}{6 Sept. 2005} & \multicolumn{2}{|c|}{5 Oct. 2005} \\
\hline & $\overline{\text { Sym }}$ & Ser & Sym & Ser \\
\hline \multicolumn{5}{|l|}{ Infected } \\
\hline Barton III & + & + & & \\
\hline Barton IV & & & - & + \\
\hline Barton V & & & - & + \\
\hline Cheyenne III & + & + & & \\
\hline Desirable III & & & - & - \\
\hline Desirable IV & & & - & + \\
\hline Kiowa V & + & + & & \\
\hline Kiowa VI & & & - & + \\
\hline \multicolumn{5}{|l|}{ Uninfected } \\
\hline Barton III & & & - & - \\
\hline Cheyenne II & & & - & - \\
\hline Desirable I & & & - & - \\
\hline Kiowa II & & & - & - \\
\hline Kiowa III & & & - & - \\
\hline
\end{tabular}

${ }^{\mathrm{z}}$ Rootstocks were grown from seed of listed cultivars, inoculated with Xylella fastidiosa or distilled water in 2001, and grafted to uninfected scions of 'Pawnee' or a 'Riverside' seedling tree in 2005.

${ }^{\mathrm{y}}$ Presence $(+)$ or absence $(-)$ of symptoms of pecan bacterial leaf scorch were recorded at the time tissue was taken for serological assay, date shown. Ser $(+)$ or $(-)$ indicates a positive or negative enzyme-linked immunosorbent assay for X. fastidiosa.

be evaluated to determine whether natural infection of rootstocks occurs.
It should be possible to reduce the degree of transmission through infected scions, about $14 \%$ in one test (Sanderlin, 2005), by visually identifying infected trees throughout the growing season and avoiding collection of scion wood from trees that develop symptoms at any time during the summer and fall. Results reported here suggest that the rate of rootstock transmission of the pathogen is much higher than the rate of scion transmission. However, it would be more difficult to identify infected rootstocks and avoid their use. Pecan grafting is typically conducted during the spring either before leaf growth or shortly after the initiation of leaf development, and symptoms of PBLS usually do not become visible until midsummer. In addition, results from this test (Table 1) and previous tests (Sanderlin, 2005) illustrate that it is not always possible to detect the presence of infection solely by occasional observation for symptoms. Symptoms may be somewhat transient, because defoliation occurs and leaves with scorch may not be present at a specific point in time. Because it can take from two months to more than a year for symptoms to develop after infection (R. S. Sanderlin, unpublished data), it would be difficult to verify that rootstocks are not infected. It can be speculated that if rootstocks are naturally infected, it would be through transmission of the pathogen by insect vectors (Gould and Lashomb, 2005). Because grafting is usually done on root- stocks that have at least 1 year's growth, there would be ample opportunity for insect transmission to occur. Although seedlings used in this study were not from the typical maternal cultivars generally used by pecan propagators (Grauke and Thompson, 1995), results indicate that rootstocks from multiple seed sources can be infected with the pathogen.

\section{Literature Cited}

Gould, A.B. and J.H. Lashomb. 2005. Bacterial leaf scorch of shade trees. 7 Nov. 2005. http:// www.apsnet.org/online/feature/bls.

Grauke, L.J. and T.E. Thompson. 1995. Rootstock development, p. 167-175. In: M.W. Smith, W. Reid, and B.W. Wood (eds.). Sustaining pecan productivity into the $21^{\text {st }}$ century. Second National Pecan Workshop Proceedings. U.S. Department of Agriculture, Agricultural Research Service, Ser. Pub. ARS-1995-3.

Sanderlin, R.S. 2005. Cultivar and seedling susceptibility to pecan bacterial leaf scorch caused by Xylella fastidiosa and graft transmission of the pathogen. Plant Dis. 89:446-449.

Sanderlin, R.S. and K.I. Heyderich-Alger. 2000. Evidence that Xylella fastidiosa can cause leaf scorch disease of pecan. Plant Dis. 84:12821286.

Sanderlin, R.S. and K.I. Heyderich-Alger. 2003. Effects of pecan bacterial leaf scorch on growth and yield components of cultivar Cape Fear. Plant Dis. 87:259-262.

Vanerwegan, J. 1975. A new grafting procedure. Pecan South 2:70-71. 